\title{
Contribution of Research Projects and Environmental Impact Assessment Studies to Fauna Biodiversity in Sudan
}

\author{
Zuheir N Mahmoud* \\ Department of Zoology, University of Khartoum, Sudan
}

Submission: April 03, 2020; Published: April 16, 2020

*Corresponding author: Zuheir N Mahmoud, Department of Zoology, Faculty of Science, University of Khartoum, Sudan

Abstract

Eighteen species of ants were recorded for the first time in Sudan including Lepisiota omeri n. sp.; Parasitological surveys of freshwater fishes of the Sudan during 2006 to 2014revealed the presence of four genera of parasitic crustacean; 42 species belonging to 19 monogenean genera parasites were collected from 26 fish species. Out of these the following five species are new to science (n. sp.): Quadriacanthus fornicatus, $Q$. pravus, Q. zuheiri, Q. mandibulatus and Dogielius senegalensis. Seven new records to the Sudan helminthes were added. These are: two cestodes (Monobothrioides tchadensis and Proteocephalus glanduligerus); one digenetic (Clinostomum complanatum larva) and three nematodes (Capillaria sp., Spinitectus sp. and Philometra bagri. Recording of Barsonella lafoni as a n. sp. of Proteocephalidean (Cestoda) from Clarias catfishes was based on material from Tarkana Lake (Kenya) and Wadi Halfa, Lake Nubia, Sudan.

Fourteen nematodes including Cucullanus mormyri sp. n. from Mormyrus caschive from Kosti (White Nile) and Procamallanus (Spirocamallanus) pseudospiralis sp. n. from Synodontis schall from Khartoum, and S. frontosus, S. nigrita and S. schall from Khashm el Girba (Atbara River). In addition to two nematodes Contracaecum sp. Third stage-larvae Type 2 and Capillariidae gen. sp., needs further evaluation. All these parasites represent new host and geographical records. With respect to fishes an apparently undescribed Haplochromis species, marked variation in Sarotherodon galilaeus populations were noticed. Paradistichodus dimidiatus and Enteromius macrops were reported for the first time from the main Nile Basin. The mormyrid species Cyphomyrus petherici and Petrocephalus keatingii, as well as the small mochokid Mochokus brevis are new locality record for the White Nile. Coptodon zilli is a new locality record for Lake Nubia. Six bird species: Pelecanus onocrotalus, Phalacrocorax africanus, Ciconia ciconia, Platalea leucorodia, Haliaetus vocifer and Pluvianus aegyptius were recorded for the first time from Lake Nubia.

Keywords: Fauna; Biodiversity; Sudan

\section{Introduction}

Sudan is endowed with diversified habitats extending from the Red Sea hot brines (Atlantis II Deep) in the east to the high peaks of Jebel Marra in the west. Its ecological zones extend from low rain fall savannah in the south to deserts in the north with the meandering River Nile and its tributaries heading north to Egypt at the Mediterranean Sea. The goods, services and values provided by the biota in these habitats are immense. In line with this is the value of corals of the Sudanese Red Sea described by Jacques Cousteau "Life abounds in bank after bank of exuberant coral structures, second only to those of The Great Barrier Reef in extent and exceeding it perhaps in splendor" [1]. The presence of some flora communities in remote and inaccessible areas calls for fund raising to fill in the gap in knowledge [2]. This holds true for fauna.

The author contributed in the following four studies: diversity of ants of Sudan based on material collected during environmental impact assessment surveys; parasitological findings from freshwater fishes collected from Kosti, Sinnar, Khashm el Girba "Parasitological survey of freshwater fishes of the Nile project" [3-5]; the diversity of fresh water fishes project [6] and the avifauna of Lake Nubia documented in "Watershed Management Framework: Nubia Lake Environmental Survey" [7].

The objective of this work is to cast light on the contribution of field work, research projects and environmental impact assessment studies to the fauna Biodiversity in Sudan based on data from four selected.

\section{Material and Methods}

Ants were picked up using a strip of paper, preserved in 70\% ethanol with one drop of glycerol. Identification of ant was based on Bolton [8-11]. The websites [10,11] contains notes on ants of the Sudan concerning location, habits, collector and authors. 
The gills of freshly killed fishes were extracted and examined in bottled water under a dissecting microscope. Live monogeneans were individually picked from the gills with fine needles and prepared for morphological studies following [12]. Parasites found in the intestine were isolated and prepared for examination following $[13,14]$ as appropriate.

For description of birds seen a binocular (B-111, 8x30 ZCF) was used. Their identification followed [15-17]. Their status information followed [18] and conservation status followed [19]. Documentation was made by a Nikon DX (AF-SNIKKOR 18-55mm 1:3.5-5.6G and 55-200mm 1:4-5.6G ED) digital camera whenever appropriate.

\section{Results and Discussion}

\section{Ants}

The findings are summarized in the following points:

a) Lepisiota omeri Taylor was described as a new Hymenoptera, Formicidae species for science from Haj Abd Alla $13^{\circ} 58>0 » N, 33^{\circ} 34>60^{\prime \prime}$ E) Sinnar State, Sudan [20]. Oxford University Museum of Natural History was the depository of the prototype L. omeri (Figure 1).

b) Eighteen species of ants were recorded for the first time in Sudan from 26 localities (Table 1).

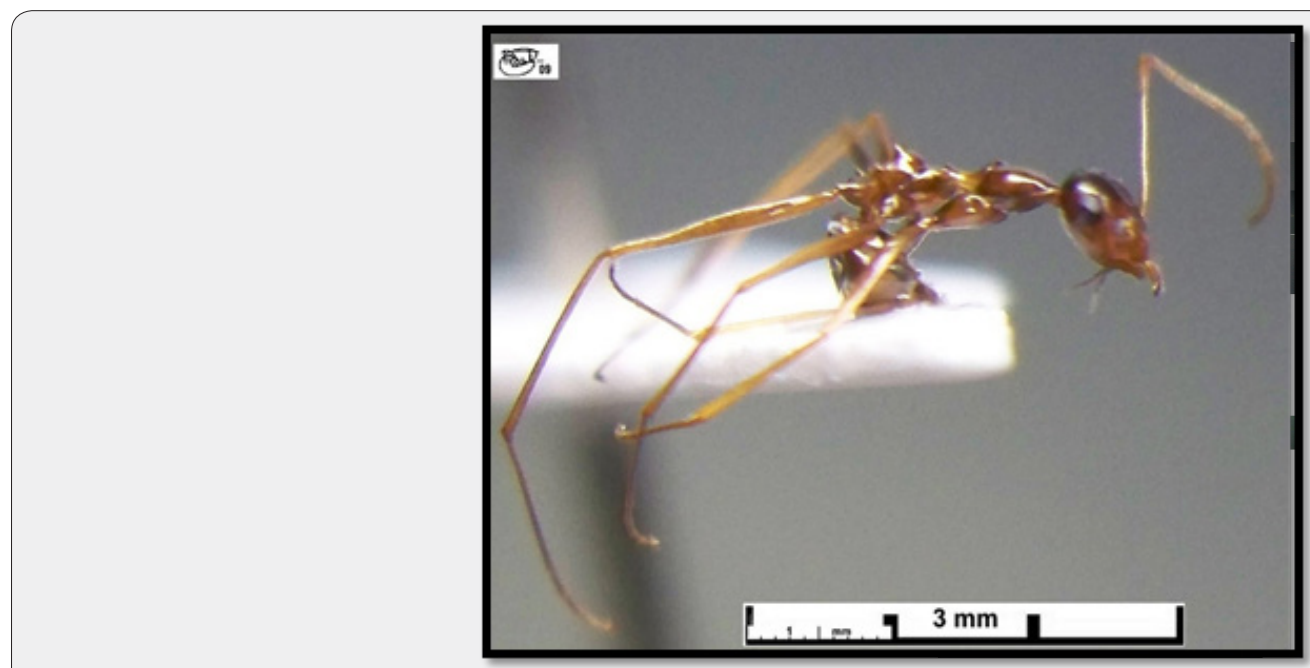

Figure 1: A worker of Lepisiota omeri.

Table 1: Ant's species recorded for the first time in Sudan.

\begin{tabular}{|c|c|}
\hline Species & Location \\
\hline \multirow{2}{*}{ Camponotus rhamses (Santschi) } & Khartoum, $15.58^{\circ} \mathrm{N} 32.53^{\circ} \mathrm{E}$ \\
\hline & Singa, $13^{\circ} 08^{\prime} 32.11^{\prime \prime} \mathrm{N} 33^{\circ} 35^{\prime} 31.27^{\prime \prime} \mathrm{E}$ \\
\hline \multirow{2}{*}{ Camponotus rufogalaucus (Jerdon) } & Khartoum, $15.58^{\circ} \mathrm{N} 32.53^{\circ} \mathrm{E}$ \\
\hline & Damazin, $11^{\circ} 46^{\prime} 31^{\prime \prime} \mathrm{N} 34^{\circ} 21^{\prime} 10^{\prime \prime} \mathrm{E}$ \\
\hline \multirow{2}{*}{ Camponotus liengmet (Forel) } & Dalanj, $11^{\circ} 52^{\prime} 59.83^{\prime \prime}$ N 2942’02.17" E \\
\hline & Sinnar, $13^{\circ} 33>N 033^{\circ} 37>\mathrm{E}$. \\
\hline \multirow{3}{*}{ Camponotus oasium (Forel) } & Wd Medani, $14^{\circ} 39^{\prime} 31^{\prime \prime} \mathrm{N}, 33^{\circ} 53^{\prime} 92^{\prime \prime} \mathrm{E}$. \\
\hline & Alrhad, $11^{\circ} 56^{\prime} 60^{\prime \prime} \mathrm{N} 27^{\circ} 25^{\prime} 60^{\prime \prime} \mathrm{E}$ \\
\hline & Nyala, $12^{\circ} 2^{\prime} 11 \mathrm{~N} 24^{\circ} 52^{\prime} 37^{\prime \prime} \mathrm{E}$ \\
\hline \multirow{3}{*}{ Catagluphis adyssinicus (Forel) } & Msawrat, $16^{\circ} 21^{\prime} 32.66^{\prime \prime} \mathrm{N} 33^{\circ} 19^{\prime} 46.71^{\prime \prime} \mathrm{E}$ \\
\hline & Arkaweet, $18^{\circ} 60^{\prime} 0^{\prime \prime} \mathrm{N} 37^{\circ} 17^{\prime} 0^{\prime \prime} \mathrm{E}$ \\
\hline & Dordape, $11^{\circ} 56^{\prime} 60^{\prime \prime} \mathrm{N} 27^{\circ} 25^{\prime} 60^{\prime \prime} \mathrm{E}$ \\
\hline \multirow{2}{*}{ Catagluphis franchettii (Menozzi) } & Abu Dlaig $15^{\circ} 53^{\prime} 47.27^{\prime \prime} \mathrm{N} 33^{\circ} 49^{\prime} 41.18^{\prime \prime} \mathrm{E}$ \\
\hline & Abu Dlaig $15^{\circ} 53^{\prime} 47.27^{\prime \prime} \mathrm{N} 33^{\circ} 49^{\prime} 41.18^{\prime \prime} \mathrm{E}$ \\
\hline \multirow{2}{*}{ Catagluphis oasium (Lush) } & Sinnar, $13^{\circ} 33^{\prime} \mathrm{N} 033^{\circ} 37^{\prime} \mathrm{E}$ \\
\hline & Solob, $20^{\circ} 26^{\prime} 15.37^{\prime \prime} \mathrm{N} 30^{\circ} 19^{\prime} 51.81^{\prime \prime} \mathrm{E}$ \\
\hline
\end{tabular}




\section{International Journal of Environmental Sciences \& Natural Resources}

\begin{tabular}{|c|c|}
\hline Lepisiota affinis (Santschi) & Wd Medani, $14^{\circ} 39^{\prime} 31^{\prime \prime} \mathrm{N}, 33^{\circ} 53^{\prime} 92^{\prime \prime} \mathrm{E}$. \\
\hline Lepisiota palpalis (Santschi) & Kosti, $13.2^{\circ} \mathrm{N} 32.7^{\circ} \mathrm{E}$ \\
\hline Lepisiota omeri (Taylor) & Haj Abd Alla, $13^{\circ} 58^{\prime} 0^{\prime \prime} \mathrm{N} 33^{\circ} 34^{\prime} 60^{\prime \prime} \mathrm{E}$ \\
\hline Paratrechina hagemanni (Forel) & Wd AlHdad, $13^{\circ} 49^{\prime} 12.06^{\prime \prime}{ }^{\circ} 33^{\circ} 32^{\prime} 31.53^{\prime \prime} \mathrm{E}$ \\
\hline Monomorium subopacum (Smith) & Shada, $20^{\circ} 08^{\prime} 32.11^{\prime \prime} \mathrm{N} 30^{\circ} 15^{\prime} 3.37^{\prime \prime} \mathrm{E}$ \\
\hline Monomorium niloticum (Emery) & Kosti, $13.2^{\circ} \mathrm{N} 32.7^{\circ} \mathrm{E}$ \\
\hline \multirow{2}{*}{ Messor ruginodis (Stitz) } & Gedarif, $14^{\circ} 66^{\prime} 37.54^{\prime \prime} \mathrm{N} 35^{\circ} 34^{\prime} 36.65^{\prime \prime} \mathrm{E}$ \\
\hline & Sinnar, $13^{\circ} 33^{\prime} \mathrm{N} 033^{\circ} 37^{\prime} \mathrm{E}$ \\
\hline \multirow{5}{*}{ Pheidole escherichii (Forel) } & Abba island, $13^{\circ} 10^{\prime} 0469^{\prime \prime} \mathrm{N} 32^{\circ} 41^{\prime} 36.69^{\prime \prime} \mathrm{E}$ \\
\hline & Port Sudan, $19.57^{\circ} \mathrm{N} 37.27^{\circ} \mathrm{E}$ \\
\hline & Haj Abd Alla, $13^{\circ} 58^{\prime} 0^{\prime \prime} \mathrm{N} 33^{\circ} 34^{\prime} 60^{\prime \prime} \mathrm{E}$ \\
\hline & Shada, $20^{\circ} 08^{\prime} 32.11^{\prime \prime} \mathrm{N} 30^{\circ} 15^{\prime} 3.37^{\prime \prime} \mathrm{E}$ \\
\hline & Damazin, $11^{\circ} 46^{\prime} 31^{\prime \prime} \mathrm{N} 34^{\circ} 21^{\prime} 10^{\prime \prime} \mathrm{E}$ \\
\hline \multirow{5}{*}{ Pachycondyla ruginota (Stitz) } & Wd AlHdad, $13^{\circ} 49^{\prime} 12.06^{\prime \prime} \mathrm{N}^{\circ} 33^{\circ} 32^{\prime} 31.53^{\prime \prime} \mathrm{E}$ \\
\hline & Toshka, $20^{\circ} 46^{\prime} 01.88^{\prime \prime}$ N 30¹8’50.14" E \\
\hline & WdAlAbas, $13^{\circ} 46^{\prime} 34.31^{\prime \prime N} 33^{\circ} 38^{\prime} 39.33^{\prime \prime} \mathrm{E}$ \\
\hline & Salara, $12^{\circ} 00^{\prime} 20.69^{\prime \prime} \mathrm{N} 29^{\circ} 43^{\prime} 13.00^{\prime \prime} \mathrm{E}$ \\
\hline & Al Maced, $15^{\circ} 15^{\prime} 26^{\prime \prime} \mathrm{N} 32^{\circ} 57^{\prime} 24^{\prime \prime} \mathrm{E}$ \\
\hline Pachycondyla analis (Fabricius) & Abbasiya, $12^{\circ} 1^{\prime} 9.01^{\prime \prime} \mathrm{N} 27^{\circ} 58^{\prime} 3.17^{\prime \prime} \mathrm{E}$ \\
\hline Dorylus eurous (Emery) & Al Bagair, $15^{\circ} 37^{\prime} 05^{\prime \prime} \mathrm{N} 32^{\circ} 75^{\prime} 77^{\prime \prime} \mathrm{E}$ \\
\hline
\end{tabular}

c) Pachycondyla ruginota was most diverse and was encountered in 10 localities, followed by Catagluphis adyssinicus in 5 localities.

\section{Parasites of freshwater fishes}

Parasitological surveys of freshwater fishes of the Sudan during 2006 to 2014 revealed the following:

a) Four genera of parasitic crustacean were record. These were Argulus, Ergasilus, Lamproglena and Lernaea and 12 species new for science were documented. Forty two species belonging to 19 monogenean genera parasites were collected from 26 fish species [3].

b) The monogenean genera identified are: Annulotrema, Bagrobdella, Bouxiella, Characidotrema, Cichlidogyrus, Dactylogyrus, Diplectanum, Diplozoon, Dogielius, Enterogyrus, Gyrodactylus, Heterobothrium, Heteronchocleidus, Onchobdella, Protoancylodiscoides, Schilbetrema, Scutogyrus, Synodontella and Quadriacanthus [3].

c) Seven species (four new) of Quadriacanthus were collected from the gills of three species of catfishes from the Nile River Basin (Sudan). These were as follows: Quadriacanthus aegypticus El-Naggar and Serag, 1986, Quadriacanthus clariadis Paperna, 1961, Quadriacanthus fornicatus n. sp., Quadriacanthus pravus n. sp., and Quadriacanthus zuheiri n. sp. from Clarias gariepinus (Clariidae); Quadriacanthus mandibulatus n. sp. from Heterobranchus bidorsalis (Clariidae); and Quadriacanthus bagrae Paperna, 1979 from Bagrus docmak (Bagridae), [21]. Parasitological survey of Labeo (Cyprinidae) horie and L. niloticus at Kosti (White Nile) and Sinnar (Blue Nile) in Sudan revealed the presence of ten species of Dactylogyrus and three species of Dogielius.

d) The Dactylogyrus species found were Dactylogyrus nathaliae Guégan; $D$. rastellus Guégan, D. retroversus; $D$. senegalensis, $D$. yassensis in addition to five unidentified Dactylogyrus sp. 1, sp. 2, sp. 3, sp.4 and species 5. They. The genus Dogielius was represented by Dogielius flosculus Guégan which was redescriped; Dogielius sennarensis identified as n. sp. L. niloticus from Sinnar, and one undescribed Dogielius species. All dactylogyrid species in this study represent new host and geographical records [5].

e) Studies of the species of Characidotrema (Monogenea: Dactylogyridae) and reported from Brycinus nurse: Characidotrema brevipenis, $C$. nursei, $C$. spinivaginus, $C$. zelotes and the new species Characidotrema pollex n. sp from Kosti and Sinnar [22]. The morphology of Schilbetrema spp. from Sudan, complemented with molecular analyses of nuclear ribosomal DNA sequence data (28S, 18S and ITS-rDNA), is still under evaluation. Eleven Schilbetrema species have been distinguished. Phylogenetic analysis showed division of Schilbetrema species into two main clades corresponding to host species (A-Schilbe intermedius and S. uranoscopus; S. mystus) [22].

f) Most of the monogenean and crustacean parasites were attached to the gills than to the fins and body surface. Two monogenean species belonging to the genus Enterogyrus were found even in stomach [3]. 
g) To the Sudan helminthes Barsonella lafoni was added as a new genus and species of Proteocephalidean (Cestoda) from Clarias catfishes was based on material from Tarkana Lake (Kenya) and Wadi Halfa, Lake Nubia, Sudan [24]. Redescription of the following cestodes: Proteocephalus sulcatus of Clarotes laticeps [25], Sandonella sandoni [26], Tapeworms of Synodontis spp., [27], Proteocephalus glanduligerus from Clarias catfishes [28] and revision on Wenyonia spp. from catfishes was based on material from Khartoum and Kosti [29]. The presence of the cestode Monobothrioides tchadensis, from Auchenoglanis sp. from Kosti and the digenetic Clinostomum complanatum larva, from Heterotis niloticus from Khartoum were confirmed.

h) Nematodes of some freshwater of Sudan and two new species were added [30]. The new species were: Cucullanus mormyri sp. n. from Mormyrus caschive from Kosti (White Nile) and Procamallanus (Spirocamallanus) pseudospiralis sp. n. from Synodontis schall from Khartoum, and S. frontosus, S. nigrita and S. schall from Khashm el Girba (Atbara River). Other 10 species were described. These were Falcaustra (=Spironoura) hexapapillata, Falcaustra sudanensis, Falcaustra similis, Cucullanus barbi,Cucullanus baylisi, Cithariniella, Multicaecum heterotis, Camallanus longicaudatus, Paracamallanus cyathopharynx, Spinitectus polli, in addition to Contracaecum sp. Third stagelarvae Type 2 and Capillariidae gen. sp. [30].

i) Taxonomic evaluation was made on the basis of both morphometrical observation and molecular methods and constituted the material of 10 publications [3-5, 21 to 30]. j) Material collected in 2014 is still under identification process.

\section{Freshwater fishes}

Moritz et al. [6] reported from Kosti (White Nile) an apparently undescribed Haplochromis species. They also noted a marked variance in Sarotherodon galilaeus populations. Specimens from Makhaleif and Kosti differ clearly in head contour, overall body shape and colouration pattern from standard Nilo-Sudanian S. galilaeus commonly occurring in the White Nile and elsewhere. They reported Enteromius macrops for the first time from the Nile Basin and confirmed the first record of Paradistichodus dimidiatus in the Nile system made by [3]. The mormyrid species Cyphomyrus petherici and Petrocephalus keatingii, as well as the small mochokid Mochokus brevis are new locality record for the White Nile [6]. Coptodon zilli is a new locality record for Lake Nubia [31].

\section{Birds of lake nubia}

The survey of birds of Lake Nubia $\left(21^{\circ} 00^{\prime} 00^{\prime \prime}\right.$ and $22^{\circ} 00.00^{\prime \prime} \mathrm{N}$, $30^{\circ} 30^{\prime} 00^{\prime \prime}$ and $31^{\circ} 30^{\prime} 00^{\prime \prime}$ E) was made in 2015 by [7] recorded 32 species falling into 13 families, while 41 species falling into 14 families were recorded by [32].

The following six species Pelecanus onocrotalus, Phalacrocorax africanus, Ciconia ciconia, Platalea leucorodia (Figure 2), Haliaetus vocifer and Pluvianus aegyptius were recorded for the first time from Lake Nubia.

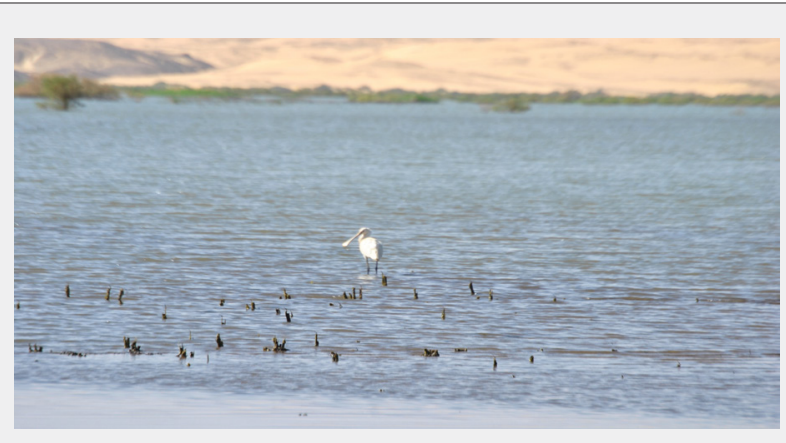

Figure 2: Platalea leucorodia, a Palearctic Eurasian Spoonbill.

Table 2: Lake Nubia Birds (1=[32], 2=[7]).

\begin{tabular}{|c|c|c|c|c|}
\hline English Name & Scientific Name & Status & 1 & 2 \\
\hline \multicolumn{5}{|c|}{ Family: Pelecanidae } \\
\hline White Pelican & Pelecanus onocrotalus & M & & + \\
\hline Pink-backed Pelican & Pelecanus rufescens & $\mathrm{RB}$ & + & + \\
\hline \multicolumn{5}{|c|}{ Family: Phalacrocoracidae } \\
\hline Greater Cormorant & Phalacrocorax carbo & M & + & + \\
\hline Reed Cormorant & Phalacrocorax africanus & M & & + \\
\hline \multicolumn{5}{|c|}{ Family: Anhingidae } \\
\hline Darter & Anhingus rufa & $\mathrm{RB}$ & + & + \\
\hline
\end{tabular}


International Journal of Environmental Sciences \& Natural Resources

\begin{tabular}{|c|c|c|c|c|}
\hline \multicolumn{5}{|c|}{ Family: Ardeidae } \\
\hline Little Bittren & Ixobrychus minutus & $\mathrm{RB} / \mathrm{P}$ & + & + \\
\hline Grey Heron & Ardea cinerea & $\mathrm{RB} / \mathrm{P}$ & + & + \\
\hline Goliath Heron & Ardea goliath & $\mathrm{RB}$ & + & + \\
\hline Purple Heron & Ardea purpurea & $\mathrm{RB} / \mathrm{P}$ & + & + \\
\hline Squacco Heron & Ardeola ralloides & $\mathrm{RB} / \mathrm{P}$ & + & \\
\hline Cattle Egret & Bubulcus ibis & $\mathrm{MB} / \mathrm{P}$ & + & + \\
\hline Great White Egret & Egretta alba & $\mathrm{P}$ & + & + \\
\hline Little Egret & Egretta garzetta & $\mathrm{RB} / \mathrm{P}$ & + & + \\
\hline Night heron & Nycticorax nycticorax & $\mathrm{RB} / \mathrm{P}$ & + & \\
\hline \multicolumn{5}{|c|}{ Family: Ciconiidae } \\
\hline Abdim;s Stork & Ciconia abdimi & MB & + & + \\
\hline White Stork & Ciconia ciconia & PW & & + \\
\hline Yellow-billed Stork & Myceria ibis & MB & + & \\
\hline Glossy Ibis & Plegadis flacinellus & $\mathrm{P}$ & + & \\
\hline \multicolumn{5}{|c|}{ Family Threskiornithidae } \\
\hline Eurasian Spoonbill & Platalea leucorodia & $\mathrm{RB} / \mathrm{P}$ & & + \\
\hline \multicolumn{5}{|c|}{ Family: Phoenicopteridae } \\
\hline Lesser Flamingo & Phoenicopterus minor & $\mathrm{N} / \mathrm{A}$ & + & + \\
\hline Greator Flamingo & Phoenicopterus ruber & PM & + & + \\
\hline \multicolumn{5}{|c|}{ Family: Antidae } \\
\hline White-faced Whistling Duck & Dendrocygna viduata & MP & + & + \\
\hline Egyptian Goose & Alopochen aegypticanus & MP & + & + \\
\hline Pintail & Anas acuta & PW & + & \\
\hline Shoveler & Anas clypeata & PW & + & \\
\hline Teal & Anas crecca & PW & + & \\
\hline Garganey & Anas querquedula & PW & + & \\
\hline \multicolumn{5}{|c|}{ Family: Accipiteridae } \\
\hline Marsh Harrier & Circus aeruginosus & PW & + & \\
\hline African Fish Eagle & Haliaetus vocifer & $\mathrm{RP}$ & & + \\
\hline Black Kite & Milvus migrans & MB/PW & + & + \\
\hline \multicolumn{5}{|c|}{ Family: Pandionnidae } \\
\hline Osprey & Pandion haliateus & $\mathrm{PW}$ & + & + \\
\hline \multicolumn{5}{|c|}{ Family: Rallidae } \\
\hline Moorhen & Gallinula chloropus & PW & + & + \\
\hline Little Crake & Porzana parva & $\mathrm{P}$ & + & + \\
\hline Coot & Fulica atra & PW & + & \\
\hline \multicolumn{5}{|c|}{ Family: Charadriidae } \\
\hline Egyptian Plover & Pluvianus aegyptius & MB & & + \\
\hline Spur-winged Plover & Vanellus spinosus & $\mathrm{RB}$ & + & + \\
\hline \multicolumn{5}{|c|}{ Family: Laridae } \\
\hline Grey-headed Gull & Larus cirrocephalus & M & + & + \\
\hline Little Gull & Larus minutes & $\mathrm{PV}$ & + & + \\
\hline White-winged Black Tern & Chlidonias leucopterus & PW & + & + \\
\hline
\end{tabular}




\section{International Journal of Environmental Sciences \& Natural Resources}

\begin{tabular}{|c|c|c|c|}
\hline & Sterna nilotica & PW & + \\
\hline Gull-billed Tern & Sterna albifrons & N/A & + \\
\hline Little Tern & Sterna dougallii & N/A & + \\
\hline Roseate Tern & Sterna hirundo & P & + \\
\hline Common Tern & Apus apus & + \\
\hline Eurasian Swift & Family: Alcedinidae & RB & + \\
\hline & Ceryle rudis & PW \\
\hline Pied Kingfisher & Alcedo atthis & + \\
\hline Eurasian Kingfisher & + \\
\hline
\end{tabular}

$B=$ Breeding record confirmed; $M=$ Migrant including on passage through this country; $P=$ breeds in Palearctic; $R=$ Resident; $V=V a g r a n t ~ a n d ~ W=$ winters (non-breeding season), N/A= information not available.

According to IUCN Red List of Threatened Species (http:// www.iucnredlist.org, 2012) all the birds listed in Table 2 are categorized as least concern (ver 3.1). The list given in Table 2 included [32] data as well.

Lake Nubia provides food for a considerable number of bird species. Based on [33] the birds of Lake Nubia can be divided into: aquatic plants feeders such as the White faced Whistling Duck; aquatic insects' feeders such as Swifts; invertebrate's feeders such as migrant waders and railsn; piscivores such as Osprey and kingfishers (Figure 3). Cattle Egret is partially dependant on aquatic food [34].

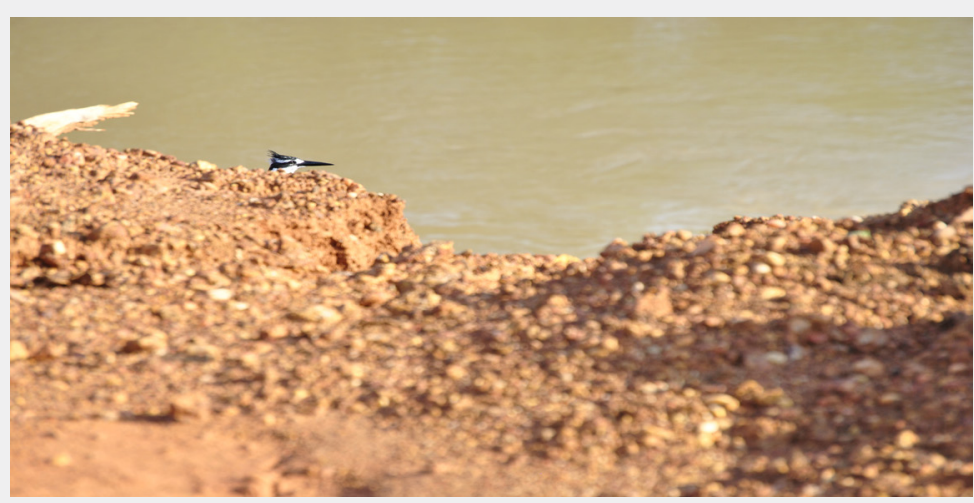

Figure 3: Ceryle rudis a Kingfisher.

The plans for future work include collection of faunal material from other localities, especially those inaccessible for the time being.

\section{Acknowledgement}

Dr. B. Taylor and Dr. Awatif K. Omer identified the ant species. The Czech, Slovenian and Swiss fish parasitologist cited in reference list are highly acknowledged.

\section{References}

1. Mahmoud ZN, Ahmed Eiman E (2010) The Sudanese Red Sea from the Hills to the Hot Brines. A. Bibliography UNESCO Chair on Marine Biology and Oceanography, Sudan, p. 204.

2. Ali OMM, Idris MF (2016) The contribution of Environmental Impact Assessment Studies to the Flora Biodiversity in Sudan. Journal of Environmental Protection 7(12): 1707-1718.

3. Blažek R, Dávidová M, Polačik M, Pravdová M, Řehulková E, et al. (2016) Nile River fish parasite survey-Nilotic fish and their tiny ectoparasite's cryptic diversity. The 7th Annual Conference for Postgraduate Studies and Scientific Research, Khartoum 27th Feb.-2nd March 2016.
4. Mahmoud ZM (2017) Parasitological Findings from Freshwater Fishes of the Nile and its Tributaries during the Last Decade (2006-2016) Int Conf of Microbiology and Applications International University of Africa, Khartoum, 23-24 April, 2017.

5. Pravdová $M$, Ondračková $M$, Blažek $R$, Mahmoud ZN, Gelnar $M$ (2018) Dactylogyrids (Platyhelminthes: Monogenea) from Sudanese Labeo spp., with a description of Dogielius sennarensis n. sp. and a redescription of Dogielius flosculus Guégan, Lambert \& Euzet. Helminthologia 55(4): 306-321.

6. Moritz T, Mahmoud ZN, Abakar M, Neumann D (2019) New and rare records of fishes from the White Nile in the Republic of the Sudan. Cybium 43(2): 137-151

7. Babiker Insaf S, Ahmed Ikram M, Mahmoud ZN, Mukhtar Huda M (2015) Watershed Management Framework: Nubia Lake Environmental Survey. A study requested by The Word Bank. p. 112.

8. Bolton B (1994) Identification Guide to the Ant Genera of the World. Harvard University Press, Cambridge, Massachusetts.

9. Bolton B, Alpert G, Ward PS, Naskrecki P (2006) BoIton's catalogue of ant of the world. Harvard University Press, Cambridge, MA, CD-ROM

10. http://antbase.org/ants/africa/new_records_sudan.htm 
11. https://www.antweb.org/

12. Musilová N, Řehulková E, Gelnar M (2009) Dactylogyrids (Platyhelminthes: Monogenea) from the gills of the African carp, Labeo coubie Rüppell (Cyprinidae), from Senegal, with descriptions of three new species of Dactylogyrus and the redescription of Dactylogyrus cyclocirrus Paperna, 1973. Zootaxa 2241: 47-68.

13. Scholz T, Hanzelov V (1998) Tapeworms of the genus Proteocephalus Weinland, 1858 (Cestoda: Proteocephalidae), parasites of fishes in Europe. Studie AVCR Academia Praha, Czech Republic, p. 119.

14. de Chambrier A (2001) A new tapeworm from the Amazon, Amazotaenia yvettae n. gen., n. sp., (Eucestoda: Proteocephalidea) from the siluriform fishes Brachyplatystoma filamentosum and B. vaillanti (Pimelodidae). Revue suisse de Zoologie 108: 303-316.

15. Williams JG, Arlott N (1986) A Field Guide to the Birds of East Africa. Collins, London. ( $6^{\text {th }}$ edn), p. 415.

16. Hollom PAD, Porter RF, Christensen S, Willis I (1988) Birds of the Middle East and North Africa. T. and A.D. Poyser.

17. www.iucnredlist.org (2012) IUCN Red List of Threatened Species.

18. Dowsett RJ, Atkinson PW, Caddick JA (2014) Checklist of the birds of Sudan.

19. http://www.iucnredlist.org

20. Taylor B, Mahmoud ZN, Omer Awatif K (2013) Ants of the Sudan. I: Lepisiota omeri Taylor (Hymenoptera, Formicidae) from a new species Haj Abd Alla, Sinnar State. Sudan Biota 1: 1-7.

21. Francová K, Mária S, Blažek R, Gelnar M, Mahmoud ZN, et al. (2017) Quadriacanthus species (Monogenea: Dactylogyridae) from catfishes (Teleosti: Siluriformes) in eastern Africa: new species, new records and first insight into interspecific genetic relationship. Parasites \& Vectors 10: 361-381

22. Eva R, Kičinjaová ML, Mahmoud ZN, Gelnar M, Seifertová M (2019) Species of Characidotrema Paperna \& Thruston, 1986 (Monogenea: Dactylogyridae) from fishes of Alestidae (Characiformes): in Africa new species, host parasites association and first insights into the phylogeny of the genus. Parasites \& Vectors 12: 1-21.

23. Francová K, Seifertová M, Eva Ř (2016) Dactylogyrids (Monogenea: Dactylogyridae) parasitizing African catfishes (Siluriformes). The 5th workshop of the European Ichthyo Parasitology, Brno Czech Republic, 28-30 November 2016
24. de Chambrier A, Scholz T, Beletew M, Mariaux J (2009) Barsonella lafoni a new genus and species of Proteocephalidean (Cestoda) from Clarias catfishes (Siluriformes: Clariidae) in Africa. Journal of Parasitology 95(1): 160-168.

25. de Chambrier A, Scholz T, Beletew M, Mahmoud ZN (2007) Redescription of Proteocephalus sulcatus (Klaptocz, 1906) (Cestoda: Proteocephalidea), a poorly known parasite of Clarotes laticeps (Pisces: Siluriformes) in Africa. Revue Suisse de Zoologie 114: 693702 .

26. de Chambrier A, Mariaux J, Sène A, Mahmoud ZN, Scholz T (2008) Sandonella sandoni (Lynsdale, 1960), An Enigmatic and morphologically Unique Cestode Parasitic in the Osteoglossiform Fish Heterotis niloticus in Africa. J Parasitol 94(1): 202-221.

27. de Chambrier A, Scholz T, Mahmoud ZN, Mariaux J, Jirku M (2011) Tapeworms (Cestoda: Proteocephalidea) of Synodontis spp. (Siluriformes) in Africa: survey of species and their redescriptions. Zootaxa 2976(1): 1-14

28. Scholz T, de Chambrier A, Beletew M, Mahmoud ZN (2008) Redescription of Proteocephalus glanduligerus (Janicki, 1928) Fuhrmann, 1933 (Cestoda: Proteocephalidea), a parasite of Clarias catfishes in Africa with a unique glandular apical organ. Journal of Parasitology 95(2): 443-449.

29. Schaeffner BC, Jirků M, Mahmoud ZN, Scholz T (2011) Revision on Wenyonia Woodland, 1923 (Cestoda: Caryophyalidea) from catfishes (Siluriformes) in Africa. Syst Parasitol 79(2): 83-107.

30. Moravec F, Scholz T (2017) Some nematodes, including two new species, from freshwater fishes of Sudan and Ethiopia. Folia Parasitologica 64.

31. Mahmoud ZN (2019) First Record of Coptodon zilli (Gervais, 1848) Cichlidiae from Lake Nubia, Sudan. Accepted for publications by Sudan Biota.

32. Nikolaus G (1987) Distribution Atlas of Sudan's Birds with Notes on Habitat and Status. Bonner Zoologische Monographien, Nr. 25.

33. Green J (2009) Birds of the Nile. In: Dumont HJ (Ed.), The Nile: Origin, Environment, Limnology and Human uses. pp. 705-720.

34. Lever C (1987) Naturalised Birds of the World. Harlow, Essex: Longman Scientific \& Technical. ISBN 0-582-46055-7, pp. 15-17.

\section{Your next submission with Juniper Publishers} will reach you the below assets

- Quality Editorial service

- Swift Peer Review

- Reprints availability

- E-prints Service

- Manuscript Podcast for convenient understanding

- Global attainment for your research

- Manuscript accessibility in different formats

( Pdf, E-pub, Full Text, Audio)

- Unceasing customer service

Track the below URL for one-step submission https://juniperpublishers.com/online-submission.php 